\title{
Floating Wetlands System: A viable alternative for water pollutants remediation
}

\author{
Soni M. Pradhanang ${ }^{1}$, Thomas Boving ${ }^{1}$, and Ehren Meisinger $^{2}$ \\ ${ }^{1}$ Department of Geosciences, University of Rhode Island, Kingston, RI, USA \\ ${ }^{2}$ Department of Marine Affair, University of Rhode Island, Kingston, RI, USA
}

\begin{abstract}
Constructed floating wetlands is viable alternative for the treatment of stormwater, combined stormwater-sewer overflow, sewage and water supply reservoirs, among others. The use of this technology also allows to enhance the habitat, and improve aesthetics to the treatment facility. In brief, the constructed floating wetlands island treatment mechanism is a combination of several components and physico-chemical processes that mimic natural bioremediation. Plant roots play a major role in treatment processes within constructed floating wetland island since the water passes directly through root system underneath the floating mat. Pathways for contaminant removal/retention in floating wetland island are: release of extracellular enzymes, development of biofilms, flocculation of suspended matter, and plant uptake. This study summarizes the findings of four monitoring studies and emphasizes on the field studies that monitored how pond contaminants responded to the floating wetlands through extensive review of existing literature.
\end{abstract}

\section{Introduction}

Urban runoff, widely referred to as stormwater, is one of the main contributors of diffused pollution to the receiving water bodies in the United States and globally [1]. Stormwater runoff is generated from impervious surfaces, such as roads, sidewalks, driveways, parking lots and rooftops. The increase in impervious surfaces in urban and peri-urban areas primarily result in increased flux of stormwater contaminants. As runoff rates and volumes increase, infiltration decrease. When vegetated surfaces are converted by impervious pavements and building or through compaction and sealing, groundwater recharge is reduced $[2,3]$. Water quality issues due to urban growth and increased impervious surface also include increased urban flooding [4], reduced baseflow [5], channel bank erosion and increase in sediment loads $[6,7,8]$, and declining water quality from excess sediment, nutrients, and heavy metals $[9,10]$, resulting in a decline in diversity of aquatic biota [11].

Urban runoff transports a variety of pollutants from pavement wear, fuel combustion, deicing salts, nutrients from fertilizer, sediment and organic matter [12,13, 14]. Federal, state, and local legislation in the U.S. mandates the use of stormwater control measures to combat these negative consequences of urban growth. Examples of such measures include bioretention, permeable pavement, water harvesting, and infiltration devices, which are often integrated into Low Impact Development (LID) strategies. Since the passage of the 
Clean Water Act (1972), wet retention basins have been used to mitigate increased postconstruction peak flow rates and are widely used as roadside best management practices (BMP) to maintain stormwater quality.

One potential retrofit for reducing nutrients in wet ponds is the use of floating treatment wetlands, also referred to as Floating Wetland Systems([FWS). FWSs function as hydroponic systems, where plants and microbes inhabit a floating mat and take up nutrients as they grow. FWSs are also known to have beneficial thermal effect as these units usually provide a good shade cover. FWSs were used to treat aquaculture effluent in Italy and showed a Total Phosphorus (TP) reduction efficiency of 65\% [15]. A mesocosm scale FWS by Van deMoortel and co-authors reported that FWS are great in treating raw domestic wastewater with removal efficiencies of $22-42 \%$ for total ammoniacal nitrogen (TAN), total nitrogen (TN), and TP [16].

\subsection{A typical Floating Wetland System}

Floating Wetlands Island Systems are proprietary or non-proprietary units of buoyant structures installed at fixed locations within ponds, lakes or slow-moving rivers. The FWS design usually follows general performance criteria, derived from the study conducted in 2012 by Headley and Tanner [17], Borne and co-authors [18] and Wanielista [19]. These are built based on the following design criteria:

- A buoyant artificial raft that floats on the surface

- Constructed from non-toxic materials, such as, but not limited to, HDPE plastic, marine grade polystyrene foam and PVC pipe

- Containing grows media planted with aquatic macrophytes whose roots extend well below the water surface but not extending to the bottom of the water body.

The FWSs application within an existing water body should:

- Have enough surface coverage to achieve high performance. The expert panel report lead by Lane and co-authors [20] recommended minimum pond surface coverage of $\sim 10 \%$ and a maximum cover of no more than $\sim 50 \%$.

- Attain $\sim 80 \%$ plant coverage on the raft by the end of the growing season.

- The buoyant raft should be placed perpendicular to the stormwater flow path.

- Be anchored to protect it from being carried away during major storms and enable retrieval for periodic maintenance.

- Use native wetland plant species and avoid invasive plants

\section{Methods}

This study summarizes the findings of four monitoring studies and emphasizes on the field studies that monitored how pond contaminants responded to the floating wetlands. An extensive review of literature relevant to the floating wetland systems was conducted. The Google Scholar search engine and a Web of Knowledge search were primarily used in combination with keywords, such as floating wetland, constructed wetlands, floating island, stormwater treatment in identifying relevant research.

\section{Results and Discussions}

Pollutant removal efficiencies of FWIs reported in five studies is presented below. 


\subsection{New Zealand}

An experimental study was conducted near Auckland, New Zealand. It consisted of sideby-side investigation of a pond without FWS and one retrofitted with FWS. The vegetation planted on the FWS system was not specified. The nutrient removal performance of the two systems was reported [21,22]. The pond served a 4.2-acre drainage area that was $75 \%$ impervious. After runoff entered into a common forebay, flows were split between two equal wet pond cells. One cell served as a control and was not planted, while the second was retrofit with an FTW that covered $50 \%$ of the pond's surface area (Table 1). A yearlong study studied nutrient removal efficiencies for 17 storm events.

Another similar study reported that overall removal of nitrogen was $12 \%$ greater in the FWS retrofitted pond compared to the control site [22]. The TN removal was associated with the organic nitrogen fraction of the total nitrogen that settled as particulate nitrogen during the study period. High nitrate removal was linked to denitrification activity within the FWS. Further it was reported that there was $27 \%$ greater removal of phosphorus by the FWS retrofit (Table 2). Similar to the TN, most of this reduction was attributed to the settling of particulate phosphorus fraction and sorption of phosphorus to the root network [22].

\subsection{North Carolina, USA}

Two wet retention ponds in Durham, NC, were evaluated for pollutant concentrations for 14 months prior to and after retrofitting with FWS [23]. The study utilized a before and after study design to evaluate the impact of the FTW retrofits, with at least 16 storm events sampled during each phase of the study. The FTW rafts were proprietary and were planted with five wetland species [Juncus effusus, Carex stricta, Spartina pectinata, Hibiscus moscheutos and Pontederia cordata].

The first wet pond [the Highway pond] drained about 32.3 acres of the roadway and had a permanent pool surface area of 0.74 acres of which $9 \%$ was covered by the FTW. The second wet pond [the Museum pond] drained about 5.9 acres of buildings and parking lots and had a permanent pool surface area of 0.12 acres of which $18 \%$ was covered by the FTW (Table 1). Both wet ponds were found effective at removing most forms of nitrogen and phosphorus prior to the FTW retrofit, but their performance on a mass load basis improved further after the FTW retrofit (Table 2). Most of the increased pond pollutant removal was attributed to improved settling of particulate nutrients, especially near the underwater root network below the FTW.

Table 1. FWI Retrofit Site Characteristics

\begin{tabular}{|l|c|c|c|c|l|}
\hline \multicolumn{1}{|c|}{ Sites } & $\begin{array}{c}\text { Drainage } \\
\text { area [acre] }\end{array}$ & $\begin{array}{c}\% \\
\text { Impervious }\end{array}$ & $\begin{array}{c}\text { Size of } \\
\text { the pond } \\
\text { [acre] }\end{array}$ & $\begin{array}{c}\text { FWSs } \\
\text { Surface } \\
\text { area } \\
\text { coverage }\end{array}$ & Plants \\
\hline $\begin{array}{l}\text { New } \\
\text { Zealand }\end{array}$ & 4.2 & $75 \%$ & & $50 \%$ & unknown \\
\hline $\begin{array}{l}\text { Highway } \\
\text { Pond, North } \\
\text { Carolina }\end{array}$ & 0.74 & $9 \%$ & $\begin{array}{l}\text { Juncus effusus, } \\
\text { Carex stricta, } \\
\text { Spartina pectinata, } \\
\text { Hibiscus moscheutos } \\
\text { and Pontederia } \\
\text { cordata }\end{array}$ \\
\hline Museum & 32.3 & $88 \%$ & 0.12 & $18 \%$ & Juncus effusus, \\
\hline
\end{tabular}




\begin{tabular}{|l|l|l|l|l|l|}
\hline $\begin{array}{l}\text { Pond, North } \\
\text { Carolina }\end{array}$ & & & & & $\begin{array}{l}\text { Carex stricta, } \\
\text { Spartina pectinata, } \\
\text { Hibiscus moscheutos } \\
\text { and Pontederia } \\
\text { cordata }\end{array}$ \\
\hline \begin{tabular}{l} 
Pond 4M, $\begin{array}{l}\text { Central } \\
\text { Florida }\end{array}$ \\
\hline $\begin{array}{l}\text { Pond 5, } \\
\text { Central } \\
\text { Florida }\end{array}$
\end{tabular} & 5.9 & $54 \%$ & 0.6 & $5 \%$ & $\begin{array}{l}\text { soft-stem bulrush } \\
\text { and Pickerelweed }\end{array}$ \\
\hline $\begin{array}{l}\text { Maryland } \\
\text { Coastal }\end{array}$ & & & 0.09 & $9 \%$ & $\begin{array}{l}\text { Soft-stem bulrush } \\
\text { and Pickerelweed }\end{array}$ \\
\hline Plain & & & & & $\begin{array}{l}\text { Decodon, Justica } \\
\text { and Hibiscus. } \\
\text { Asclepia } \text { and } \\
\text { Pontederia }\end{array}$ \\
\hline
\end{tabular}

\subsection{Central Florida, USA}

Two wet ponds, identified as Pond $4 \mathrm{M}$ and Pond 5, near the campus of the University of Florida, Gainesville were retrofitted for pollutant removal efficiency study [24, 25]. Pond $4 \mathrm{M}$ had a 0.6 -acre surface area, was not aerated, and had about 5\% FWS cover. Pond 5 had a 0.09 -acre surface area, a fountain for aeration, and an estimated 9\% FWS cover (Table 1). The two ponds had different raft technology and planting media but were both planted with soft-stem bulrush and pickerelweed. Both ponds were heavily influenced by groundwater, which produced significant pond outflows during non-storm periods.

The field experiment consisted of before and after monitoring and storm and non-storm sampling. One to $4 \%$ nutrient removal was reported from the Pond $4 \mathrm{M}$ while higher removal rates for TN [48\%] and TP [16\%] were reported for Pond 5 [25] (Table 2).

Table 2. Pollutants removal performances for FWS retrofits. TAN: total ammoniacal nitrogen; TN: total nitrogen; TP: total phosphorus.

\begin{tabular}{|l|l|l|l|l|l|l|}
\hline \multirow{2}{|c|}{ Sites } & \multicolumn{2}{|c|}{ TN removal } & \multicolumn{2}{c|}{ TP removal } & \multicolumn{2}{c|}{ TSS removal } \\
\hline & $\begin{array}{c}\text { Pre- } \\
\text { retrofit }\end{array}$ & $\begin{array}{c}\text { Post- } \\
\text { retrofit }\end{array}$ & $\begin{array}{c}\text { Pre- } \\
\text { retrofit }\end{array}$ & $\begin{array}{c}\text { Post- } \\
\text { retrofit }\end{array}$ & $\begin{array}{c}\text { Pre- } \\
\text { retrofit }\end{array}$ & $\begin{array}{c}\text { Post- } \\
\text { retrofit }\end{array}$ \\
\hline New Zealand & $17 \%$ & $29 \%$ & $22 \%$ & $55 \%$ & $22 \%$ & $44 \%$ \\
\hline Highway Pond, North Carolina & $36 \%$ & $48 \%$ & $36 \%$ & $39 \%$ & $92 \%$ & $78 \%$ \\
\hline Museum Pond, North Carolina & $59 \%$ & $88 \%$ & $57 \%$ & $88 \%$ & $89 \%$ & 95 \\
\hline Pond 4M, Central Florida & na & & na & $12 \%$ & Na & na \\
\hline Pond 5, Central Florida & na & $48 \%$ & na & $16 \%$ & Na & na \\
\hline Maryland Coastal Plain & $\begin{array}{l}\text { Reported as nitrification } \\
\text { and denitrification rate }\end{array}$ & \multicolumn{2}{l|}{ Not available } & \\
\hline
\end{tabular}

\subsection{Maryland Coastal Plain, USA}

The case study from the Maryland Coastal Plain focused on the evaluation of floating treatment wetlands in stormwater retention ponds on poultry farms to reduce nutrient loading [26]. They reported that FWS grow and perform well in Mid-Atlantic region. The authors reported that denitrification processes dominated in the FWS, resulting in high nitrogen removal rate. The monitored water bodies were stormwater runoff ponds with pollutant sources mainly related to agricultural and poultry production practices. 
A yearlong study was conducted in a pond retrofitted with 3 FWSs. Sediment core samples and water samples were collected during the growing season and analyzed for oxidation-reduction potential [ORP] and denitrification potential. The study reported the FWS matrix having high efficiency [5 to 7 times higher] than the pond sediment samples. The peripheral parts of the FWSs exhibited the highest denitrification rates compared to the central parts of the FWS. The team conducted additional studies at the same site with same FWSs and found that FWSs were generally suitable for most of wetland plants (Table 1). However, plant species such as, Asclepia and Pontederia did not grow as well as they were subject to fowl herbivory. Nitrogen uptake ranged from 0.2 to $6.7 \mathrm{mg} \mathrm{N} / \mathrm{ft}^{2} \mathrm{FWS} / \mathrm{day}$, whereas denitrification rates ranged from 1.3 to $4.1 \mathrm{mg} \mathrm{N} / \mathrm{ft}^{2} \mathrm{FTW} /$ day [26].

\section{Summary}

FWS is a comparable new approach to manage nutrient flow and other water pollutants in stormwater runoff treatment structures, like retention ponds. Five recent studies present data from investigations of the removal of nitrogen and phosphorous using different type of plant assemblages. Removal mechanisms were identified as settling of sorbed nutrient after passage of the FWS on the pond bottom, conversion, and plant uptake. The reviewed studies were carried out under different climatic conditions, ranging from moderately warm to subtropical and in water bodies receiving different types of runoff. Overall, the studies strongly suggest that the FWS concept is working as envisioned and can be applied to a broad spectrum of conditions. More research is required to study optimal plant assemblages and FWS effectiveness for treating other pollutants frequently present in stormwater runoff.

\section{Acknowledgement}

This research is supported by United States Department of Agriculture Hatch S-1063 grant.

\section{References}

1. V. Novotny. Water quality: diffuse pollution and watershed management. John Wiley \& Sons; [2003].

2. T. D. Fletcher, H. Andrieu, P. Hamel. Understanding, management and modelling of urban hydrology and its consequences for receiving waters: A state of the art. Advances in water resources. [2013] Jan 1;51:261-79.

3. G. Yang, L.C. Bowling, K. A. Cherkauer, B. C. Pijanowski. The impact of urban development on hydrologic regime from catchment to basin scales. Landscape and Urban Planning. [2011] Nov 30;103[2]:237-47.

4. K. L. Meierdiercks, J. A. Smith, M. L. Baeck, A. J. Miller. Analyses of Urban Drainage Network Structure and its Impact on Hydrologic Response 1. JAWRA Journal of the American Water Resources Association. [2010] Oct;46[5]:932-43.

5. P. Hamel, E. Daly, T. D. Fletcher. Source-control stormwater management for mitigating the impacts of urbanisation on baseflow: A review. Journal of Hydrology. [2013] Apr 2;485:201-11.

6. C. M. Cianfrani, W. C. Hession, D. M. Rizzo. Watershed imperviousness impacts on stream channel condition in southeastern Pennsylvania 1. JAWRA Journal of the American Water Resources Association. [2006] Aug;42[4]:941-56. 
7. O. Navratil, P. Breil, L. Schmitt, L. Grosprêtre, Albert MB. Hydrogeomorphic adjustments of stream channels disturbed by urban runoff [Yzeron River basin, France]. Journal of Hydrology. [2013] Apr 2;485:24-36.

8. E. J. Nelson, D. B. Booth. Sediment sources in an urbanizing, mixed land-use watershed. Journal of Hydrology.[ 2002] Jul 30;264[1-4]:51-68.

9. R. O. Carey,G. J. Hochmuth, C. J. Martinez, T. H. Boyer, M. D. Dukes, G. S. Toor, J. L. Cisar. Evaluating nutrient impacts in urban watersheds: Challenges and research opportunities. Environmental Pollution. [2013] Feb 1;173:138-49.

10. B. E. Hatt, A. Steinel,A. Deletic, T. D. Fletcher. Retention of heavy metals by stormwater filtration systems: breakthrough analysis. Water Science and Technology. [2011] Nov 1;64[9]:1913-9.

11. M. Alberti, D. Booth, K. Hill, B. Coburn, C. Avolio, S. Coe, D. Spirandelli. The impact of urban patterns on aquatic ecosystems: An empirical analysis in Puget lowland sub-basins. Landscape and urban planning. 2007 May 20;80[4]:345-61.

12. J. P. Hartigan, T. F. Quasebarth, E. Southerland. Calibration of NPS model loading factors. Journal of Environmental Engineering. [1983] Dec;109[6]:1259-72.

13. D. E. Line, N. M. White. Effects of development on runoff and pollutant export. Water Environment Research. [2007] Feb 1;79[2]:185-90.

14. J. E. Schoonover, B. G. Lockaby. Land cover impacts on stream nutrients and fecal coliform in the lower Piedmont of West Georgia. Journal of hydrology. [2006] Dec 15;331[3-4]:371-82.

15. G. De Stefani, D. Tocchetto, M. Salvato, M. Borin. Performance of a floating treatment wetland for in-stream water amelioration in NE Italy. Hydrobiologia. [2011] Oct 1;674[1]:157-67

16. A. M. Van de Moortel, G. Du Laing, N. De Pauw, F. M. Tack. The role of the litter compartment in a constructed floating wetland. Ecological engineering. [2012] Feb $1 ; 39: 71-80$.

17. T.R. Headley, C. C. Tanner. Constructed wetlands with floating emergent macrophytes: an innovative stormwater treatment technology. Critical Reviews in Environmental Science and Technology. [2012] Jan 1;42[21]:2261-310.

18. K. E. Borne, E. A. Fassman-Beck, R. J. Winston, W. F. Hunt, C. C. Tanner. Implementation and maintenance of floating treatment wetlands for urban stormwater management. Journal of Environmental Engineering. [2015] Apr 16;141[11]:04015030.

19. M. P. Wanielista,N. B. Chang, M. Chopra, Z. Xuan, K. Islam, and Z. Marimon. Floating wetland systems for nutrient removal in stormwater ponds. [2012]. Stormwater Management Academy. Civil, Environmental, and Construction Engineering Department University of Central Florida, Tallahassee, FL.

20. S. Lane, D. Sample, A. Lazur, R. Winston, C. Streb, D. Ferrier, L. Linker, K. Brittingham, T. Schueler, C. Lane, C. S. Network. Recommendations of the Expert Panel to Define Removal Rates for Floating Treatment Wetlands in Existing Wet Ponds.

21. K. E. Borne, C. C. Tanner, E. A. Fassman-Beck. Stormwater nitrogen removal performance of a floating treatment wetland. Water Science and Technology. [2013] Oct 1;68[7]:1657-64. 
22. K. E. Borne. Floating treatment wetland influences on the fate and removal performance of phosphorus in stormwater retention ponds. Ecological engineering. [2014] Aug 1; 69:76-82.

23. R. J. Winston, W. F. Hunt, S. G. Kennedy, L. S. Merriman, J. Chandler, D. Brown. Evaluation of floating treatment wetlands as retrofits to existing stormwater retention ponds. Ecological Engineering. [2013] May 1; 54:254-65.

24. M. P. Wanielista, N. B. Chang, M. Chopra, Z. Xuan, K. Islam, Z. Marimon. Floating wetland systems for nutrient removal in stormwater ponds. Stormwater Management Academy. Civil, Environmental, and Construction Engineering Department University of Central Florida, Tallahassee, FL. [2012] Sep.

25. N. B. Chang, M. Wanielista, M. Chopra. Floating Wetland Systems for Nutrient Removal in Stormwater Ponds. [2012]

26. J. K. Lowman. Evaluation of floating treatment wetlands in stormwater retention ponds on poultry farms to reduce nutrient loading. Towson University Institutional Repository. 2013 Feb 26. 